\title{
„Фað var eitthvað meira parna“: Mat á námi með áherslu á vellíðan barna
}

\author{
Daníel Steingrímsson og Kristín Karlsdóttir
}

Abstract Um höfundana About the authors $>$ Heimildir

Mat á námi og vellíðan barna er hluti af starfi leikskóla samkvæmt Ađalnámskrá leikskóla 2011. Hér verður greint frá rannsókn sem gerð var með sex starfsmönnum eins leikskóla á Íslandi og er hluti af samstarfsrannsókn (e. collaborative action research) sem unnin var í samstarfi RannUng (Rannsóknarstofu í menntunarfræði ungra barna) og fimm leikskóla á Stór-Reykjavíkursvæðinu. Í upphafi auglýsti RannUng eftir pátttakendum sem hefðu hugá að vinna að próun mats í leikskólum. Í peim leikskóla sem hér er fjallað um voru pátttakendur aðstoðarleikskólastjóri ásamt tveimur leikskólakennurum og premur leiðbeinendum á einni leikskóladeild með 24 börnum sem flest voru priggja ára í upphafi vetrar. Rannsóknin stóð yfir frá september 2016 til maí 2017. Markmið rannsóknarinnar var að starfsfólk ígrundaði eigin starfshætti og próaði aðferðir við mat á námi og vellíðan barna. Rannsóknargögn byggja á viðtölum og athugunum sem greind voru í peim tilgangi að sýna ferli framkvæmdarinnar og stöðu pess mats sem fram fór á deildinni. Niðurstöður benda til pess að mat á námi og vellíðan barnanna hafi í upphafi vetrar fyrst og fremst farið fram í samræðum starfsfólks, sem taldi að skráning væri ekki næg í leikskólastarfinu. Фað sem metið var í upphafi vetrar tengdist hljóðvitund, málproska, félagshæfni, hegðun og almennum proska. Mat petta fór fram fyrir foreldraviðtöl og í sérstökum tilvikum. Hugmyndir starfsfólks um mat á námi og líðan breyttust yfir veturinn. Starfsfólk fór að fylgjast betur með líðan barna í stað hegðunar peirra. Próaðar voru námssögur og var staða barnanna og geta greind og ígrunduð út frá námssögunum. Skráning námssagna reyndist falla vel að pví mati sem pegar var framkvæmt á deildinni. Fagvitund leikskólakennaranna skerptist í ferlinu og peim fannst peir geta virkjað pað sem peir höfðu áður lært og reynt um börn, áhuga peirra og líðan. Leiðbeinendurnir töldu sig hafa lært mikið af pátttöku í rannsókninni og próað faglegri starfshætti, ásamt pví að ígrundun um börnin og athafnir peirra varð peim tamari. Pátttakendur juku vitund sína um líðan barna og stöðu peirra innan barnahópsins. Peir tóku betur eftir börnum sem voru utanveltu í barnahópnum. Samstarfsrannsóknin jók fagvitund jafnt leikskólakennara sem leiðbeinenda, pó kom fram í viðtölum að lærdómur peirra síðarnefndu virtist enn meiri. Pátttakan í rannsókninni dró athygli peirra að börnunum, námi peirra og líðan og gerði peim kleift að mæta börnunum með pví að lesa í tjáningu peirra. Með pessu móti veittu námssöguskráningarnar peim nýja innsýn í heim barnanna.

Efnisord: Mat á námi, vellíðan barna, samstarfsrannsókn, leikskólamenntun, fagleg ígrundun 


\section{Inngangur}

Í Aðalnámskrá leikskóla er gert ráð fyrir að fram fari mat á námi og líðan barna í leikskólum. Í tengslum við skólanámskrá er leikskólunum sjálfum látið eftir að móta og próa ferlimiðaðar matsaðferðir en peim er ætlað að safna upplýsingum um pað sem börn fást við og hafa áhuga á (Mennta- og menningarmálaráduneytið, 2012). Í pjóđfélagi sem stjórnast af kröfu um árangur og framfarir er mikilvægt að nema staðar og velta fyrir sér hvað er í fyrirrúmi við skipulag náms og hvaða aðferðir eru notaðar til að meta pað. Ein matsaðferð er að skrá námssögur sem segja frá pátttöku barna í leik og öðrum viðfangsefnum. Matið getur fjallað um margbreytilega og flókna pætti sem koma fram í samskiptum barna, en pví er jafnframt ætlað að hafa í forgrunni félags- og tilfinningalega pætti náms. Námssögur eru stuttar sögur sem skráðar eru með fjölbreyttum hætti í leikskólastarfi, svo sem pegar börn leika sér og fást við skapandi viðfangsefni. Námssöguaðferðinni er ætlað að hafa í forgrunni félagslega og tilfinningalega pætti náms og kallar hún pví á skoðun á margbreytilegum viðfangsefnum og flóknum samskiptum í leikskólastarfinu. Í skráningarferlinu eru samskipti barna greind og ígrunduð af gaumgæfni og geta pví falið í sér huglægt mat pess sem skráir. Sögunum er ætlað að varpa ljósi á getu, nám, proska og líðan barna (Kristín Karlsdóttir og Anna Magnea Hreinsdóttir, 2015; Kristín Karlsdóttir og Bryndís Garðarsdóttir, 2008).

Prátt fyrir að rannsóknir sýni að væntingar íslenskra foreldra gagnvart leikskólagöngu barna sinna beinist fyrst og fremst að félagsfærni, samskiptum, virðingu og að sýna öðrum samkennd (Jóhanna Einarsdóttir, 2017), sækir sú tilfinning að, pegar talað er við leikskólastarfsfólk, að vaxandi utanaðkomandi prýstingur sé á að sýna fram á mikilvægi leikskólans sem fyrsta skólastigsins. Ætla má að mörgum leikskólakennurum líki ekki hugmyndin um staðlaðar matsaðferðir í leikskólastarfi sem samræmast ekki hugmyndum leikskólakennaranna um bernskuna og nám sem fram fer með pátttöku barna í sjálfsprottnum leik. Dví er pessari rannsókn ætlað að próa matsaðferðir í takt við skólanámskrá pátttökuleikskólans en taka jafnframt mið af pví sem fram kemur um mat í Aðalnámskrá leikskóla (Mennta- og menningarmálaráđuneytið, 2012).

Í leikskólanum, sem tók pátt í peirri samstarfsrannsókn (e. collaborative action research) sem hér er til umfjöllunar, var valin sú leið að innleiða gerð námssagna í starfið. Með pví vildu stjórnendur efla pað námsmat sem pegar var unnið í leikskólanum. Mikilvægi rannsóknarinnar felst í pví að pátttakendur í leikskólanum, sem voru leikskólakennarar og leiðbeinendur á einni deild, leituðu leiða til að próa aðferðir til að meta nám og líðan barna og stuðla pannig að pví að leikskólinn mætti kröfum aðalnámskrár um ferlimiðað mat en ekki síður pann pátt matsins að lesa í tjáningu barnanna og styðja pannig við áhrif peirra í leikskólastarfinu.

Hér er um að ræða samstarfsannsókn sem unnin var í samstarfi starfsfólks í leikskóla, meistaranema og háskólakennara með áherslu á að lýsa pví ferli sem átti sér stað í framkvæmdinni. Gögnum var safnað með viðtölum og athugunum og pau greind með pví að rýna í hvernig aðferðir voru próaðar af leikskólakennurum og leiðbeinendum. Loks var viðhorfum peirra og upplifun af pátttöku lýst. Dar sem markmið samstarfsrannsóknarinnar var að pátttakendur próuðu aðferðir til að meta nám og vellíðan barna í leikskólanum er parft að skoða hugtökin velferð og vellíðan sem er stuðst við í Aðalnámskrá leikskóla (Mennta- og menningarmálaráðuneytið, 2012).

\section{Hugtökin velferð og vellíðan}

Degar Aðalnámskrá leikskóla (Mennta- og menningarmálaráđuneytið, 2012) er skoðuð má sjá аð fjallað er um velferð (e. welfare) og vellíðan (e. well-being) barna í nánast hverjum kafla. Hugtökin eru ekki sérstaklega skilgreind í námskránni en út frá samhengi orðanna má ætla að velferð tengist í senn huglægum efnislegum og félagslegum páttum (Margrét Héđinsdóttir, Fanný Gunnarsdóttir og Erla Kristjánsdóttir, 2013). Huglæg velferð tengist hugmyndum um sjálfið, reglum sem hver og einn setur sér, trú og von, á hvaða grundvelli maður byggir innra líf sitt. Efnisleg velferð snýr að efnislegum gæðum og möguleikum til pátttöku í starfi, menntun og félagslífi. Félagsleg velferð snýr að persónulegu tengslaneti, bæði tengslum við annað fólk 
en líka við stjórnsýslu, félagskerfið og stjórnmál, hvernig fólk getur haft áhrif á umhverfi sitt. Dessir prír pættir snerta flesta pætti daglegs lífs og sýna að velferð er mikilvæg fyrir líðan barns í nútíð og framtíð. Dví er velferð barna á ábyrgð allra peirra aðila sem koma að umönnun peirra; svo sem heimila, leikskóla og heilbrigðisyfirvalda en er jafnframt í samræmi við rétt barna til umönnunar eins og fram kemur í Samningi Sameinuðu pjóðanna um réttindi barnsins (1989). Í annarri grein laga um leikskóla kemur eftirfarandi fram: „I leikskólum á velferð og hagur barna að vera leiðarljós í öllu starfi. Veita á börnum umönnun og menntun, búa peim hollt og hvetjandi uppeldisumhverfi og örugg náms- og leikskilyrði.“ (lög um leikskóla nr. 90/2008). Velferð barna fer pannig eftir pví umhverfi og peim skilyrðum sem pau búa við, og er á ábyrgð peirra aðila sem koma að umönnun barna, par með talið heimili barna. Út frá aðalnámskránni má túlka hin tilvitnuðu orð svo að velferð sé grundvöllur vellíðanar og skiptir pví máli að börnum líði vel bæði í leikskóla og heima.

Í pessari grein er aðallega vísað til hugtaksins vellíðan út frá tveimur mismunandi fræðilegum sjónarhornum. Рað er annars vegar hvernig sjálfsmynd barns birtist í félagslegu samhengi leikskólans (Carr, 2001; Carr og Lee, 2019; Laevers, 1994) og hins vegar hvort barn lítur á eigin getu sem áhugaverða leið til að læra og bæta sig eða leitar fremur eftir mati annarra (Dweck, 2017; Dweck og Leggett, 1988; Smiley og Dweck, 1994). Samkvæmt pessum hugmyndum birtist vellíðan barna í leikskóla í pví hvernig pau fást við viðfangsefni, finna lausnir og eiga samskipti við aðra. Pannig leitast leikskólakennarar eftir pví að greina hvort börn virðast njóta pess að vera pátttakendur í samskiptum, eru opin og móttækileg gagnvart pví sem gerist í leikskólanum, tjá sig um eigin vilja og skoðanir og virðast oft geta trúað á eigin getu.

Vellíðan barna snýst pó ekki eingöngu um hvernig starfsfólk leikskóla sér hana með pví að lesa í tjáningu barna heldur tengist hún einnig sjálfsmynd barns og hvernig barnið tjáir sig um eigin vellíðan (Lillemyr, Sobstad, Marder og Flowerday, 2011). Dví má segja að hugtakið vellíðan sé víðtækt og margbætt, og tæplega unnt að meta pað með einni aðferð. Раð að meta vellíðan krefst fjölbreyttra aðferða sem fela aldrei í sér leit að einu réttu svari. Allar skráningar og ígrundun um barnið á meðal starfsfólks og með foreldrum hafa pað að markmiði að meta líðan barnsins með heilsteyptum hætti. Dað tekur tíma, krefst polinmæði og samvinnu.

Í leikskólastarfi hafa margvíslegir pættir í skipulagi áhrif á líðan barna. Viðhorf starfsfólks til barna og náms peirra, efniviður, húsnæði, nánasta umhverfi, fjöldi menntaðra leikskólakennara og stefna leikskóla eru pættir sem hafa áhrif á hvernig starf leikskóla er skipulagt. Eins og komið hefur fram hafa hugmyndir starfsfólks leikskóla um börn áhrif á skipulag leikskólastarfs. Endurskoðun á skipulagi út frá vellíðan barna hefur reynst hafa jákvæð áhrif á líðan peirra í pá veru að pau finni fyrir öryggi og að pau tilheyri hópnum. Einnig hefur slík endurskoðun áhrif á starf leikskóla og starfsánægju starfsfólks (Sara Margrét Ólafsdóttir, 2013). Til pess að börnum líði vel parf skipulag leikskólastarfsins að vera í sífelldri mótun auk pess sem taka parf mið af líðan barna og starfsánægju starfsfólks. Í ljósi pess er gagnlegt að leita leiða sem fela í sér mat á pessum páttum.

\section{Mat á velferð og vellídan}

Almennt er lítið fjallað um hvernig mat á líðan barna skuli fara fram í Aðalnámskrá leikskóla. bó kemur fram að í leikskólum sé upplýsingum safnað um pað sem börn fást við og að próaðar séu aðferðir til að meta nám og velferð barnanna. Nánari útfærsla er lögð í hendur starfsfólks hvers leikskóla sem ætlað er að próa fjölbreyttar leiðir til að „safna, skrá, skipuleggja og greina upplýsingar um proska barna, nám, vellíðan og færni og móta sérstakt vinnulag par um“ (Menntaog menningarmálaráduneytið, 2012).

Í kjölfar útkomu Aðalnámskrár leikskóla 2011 var gefið út Demahefti um námsmat íleikskólum (Menntaog menningarmálaráđuneytið, 2013). Í pví er byggt á pví sem kemur fram í ađalnámskrá um mat en að auki er bætt við ítarefni um hvernig matið getur farið fram. Í pemaheftinu kemur fram 
að pegar barn lýkur leikskóladvöl á pað að hafa fengið tækifæri til að próa með sér fjölbreytta hæfni í samskiptum, læsi, sjálfbærni, vísindum og sköpun auk pess að kunna að stuðla að eigin heilbrigði og vellíðan. Í pemaheftinu er lögð áhersla á að mat skuli fara fram í samvinnu og með pátttöku leikskólakennara, annars starfsfólks leikskóla, foreldra og barna. Dannig er lögð áhersla á heildstætt mat en ekki afmarkaða færnipætti, auk aðkomu hlutaðeigandi aðila, s.s. fjölskyldna barnanna. Markmiðið er að börn verði eins virkir pátttakendur í mati á eigin námi og vellíðan eins og mögulegt er. Samkvæmt nýlegri íslenskri rannsókn um vellíðan barna í leikskóla (Sara Margrét Ólafsdóttir og Bryndís Garðarsdóttir, 2016) er lögð áhersla á mikilvægi pess að leita eftir viðhorfum barna. Leiddar eru líkur að pví að fái börn tækifæri til að tjá áhuga sinn og ákveða hvað pau vilja fást við auki pað vellíðan peirra. Баð sama má segja um pátttöku barna í mati á eigin námi.

Samkvæmt pemaheftinu er ætlunin að í mati sé börnunum sjálfum veitt tækifæri til að verða meðvituð um eigin líðan, tjá hugsanir sínar og tilfinningar og setja sig í spor annarra. Dannig er matinu einnig ætlað аð stuðla að pví að börn upplifi sig sem skapandi, forvitna rannsakendur og virka pátttakendur í nærsamfélaginu (Mennta- og menningarmálaráðuneytið, 2013). Í pessum leiðbeiningum, sem í pemaheftinu felast, er m.a. bent á pá aðferð að safna gögnum í ferilmöppu sem sýnir ferli náms og proska barnsins í gegnum leikskóladvölina. Pættirnir, sem í pemaheftinu segir að börn eigi að fá tækifæri til að upplifa, gefa vísbendingar um líðan barnsins og eru sýnilegir í ferilmöppunni. Í ferilmöppu eiga að koma fram upplýsingar sem sýna að barnið sé öruggt, heilbrigt og að borin sé virðing fyrir pví sem einstaklingi. Í pemaheftinu kemur einnig fram að í leikskóla skuli séð til pess að börn borði hollan mat, hvíli sig, hreyfi sig og hafi aðgang að fjölbreyttum viðfangsefnum. Parf ferilmappan að sýna að barnið uni sér glatt yfir daginn, að pví virðist líða vel og sé í tilfinningalegu jafnvægi. Í leikskólastarfinu skal barnið stutt til áhrifa og til að tjá líðan sína og skoðanir (Mennta- og menningarmálaráðuneytið, 2013).

Viðhorf leikskólakennara og leiðbeinenda til bernskunnar móta pær ákvarðanir sem peir taka varðandi skipulag og námskrárgerð (Jóhanna Einarsdóttir, 2008), par með talið mat og matsaðferðir. Dessi viðhorf eru ýmist meðvituð eða ómeðvituð og pví er aðkallandi að peir sem vinna með börnum velti viðhorfum sínum fyrir sér svo tryggja megi hag barnanna.

\section{Viðhorf til barna}

Nám og proski barna á sér stað í samvinnu og með gagnkvæmum samskiptum og tengslum í félagslegum aðstæðum. Detta kemur fram í grein Jóhönnu Einarsdóttur (2008) og rímar við pá niðurstöðu Bae (2009) að lýðræðislegir starfshættir felist ekki eingöngu í pví að gefa börnum kost á að velja viðfangsefni í formlegu ferli heldur ekki síður í pví pegar börnum er gefin rödd og á pau er hlustað. Samkvæmt pessum hugmyndum fer nám ekki fram í einstaklingsbundnu vitrænu ferli barns heldur krefst pað samvinnu og samskipta við leikskólakennara og önnur börn. Auk pess hefur ólík sýn leikskólakennara og annars starfsfólks á börn og bernskuna áhrif í leikskólastarfi (Prout og James, 2015). Dví er mikilvægt að starfsfólk leikskóla líti í eigin barm og skoði hvort hugmyndir pess og starfshættir samræmist pví sem pað telur vera rétt, gott og heilnæmt fyrir nám og líðan barna í nútímasamfélagi.

Rannsóknir hafa sýnt að leikskólakennurum pyki mikilvægt að börn séu ánægð og líði vel í leikskóla (Jóhanna Einarsdóttir, 2008, 2017). Fram kemur að peir leggi áherslu á félagsleg samskipti, virðingu fyrir öðrum og samlíðan. Eftir sem áđur hafa komið fram ólík viðhorf leikskólakennara um tilgang leikskólastarfs. Sumir líta á leikskóla sem undirbúning undir grunnskóla á meðan aðrir nota óbeinar kennsluaðferðir sem einkennast af frjálsræði og skapandi verkefnum með börnum (Jóhanna Einarsdóttir, 2008). Ætla má að í sumum leikskólum sé stuðst við blöndu af pessum tveimur nálgunum. Đó ber að halda pví til haga að viðmót kennara og samskipti við börn skiptir ekki síður máli en pær áherslur í starfsháttum sem viðkomandi leikskóli styðst við (Jóhanna Einarsdóttir, 2008; Kristín Karlsdóttir, 2017). 
Samkvæmt eftirtöldum hugmyndum um börn og barnæsku, sem próast hafa á undanförnum áratugum, er litið á pau með eftirfarandi hætti: 1) börn sem góð og slæm, 2) börn sem óskrifað blað eða börn sem feta fyrir fram ákveðna stigu og 3) börn sem varnarlaus eða sterk og hæf (Dahlberg, Moss og Pence, 2007; Jóhanna Einarsdóttir, 2008). Баð hefur verið ríkjandi i íslenskri menningu að flokka börn sem góð eða slæm, t.d. fjalla mörg sönglög, bækur og vísur um óknytti barna og nauðsyn pess að pau séu góð. Раð er reynsla Daníels Steingrímssonar, annars höfundar pessarar greinar, að enn er notast við efni sem dregur upp svarthvíta mynd af pví hvernig börn eiga að haga sér, t.d. að vera stillt og prúð. Á síðari árum hafa hugmyndir um barnæsku próast enn frekar og tekið mið af samfélagsbreytingum par sem tengt er við atriði eins og tæknipróun, kynlífsvæðingu og jafnrétti kynja. Til dæmis kemur fram í rannsókn Pórdísar Dórðardóttur og Steinunnar Helgu Lárusdóttur (2016) að enn sé megináhersla á að stúlkur séu prúđar og stilltar en drengir megi vera óstýrilátir.

Hætt er við að starfshættir í leikskólum endurspegli pessi viðhorf að einhverju leyti, en í niðurstöðum sænskrar rannsóknar kemur fram að pær aðferðir sem leikskólakennarar beita í starfi með börnum endurspegli ólíka sýn og starfshætti (Johansson, 2004). Dví má í fyrsta lagi spyrja hversu sterk áhersla er á að fullorðnir viti betur en börn og að nám barnanna sé tengt hugmyndum um proska, pað er að börn læri pegar pau ná ákveðnum proska. Í öðru lagi hvort og að hvaða marki sú sýn er til staðar í leikskólum að stjórna purfi hegðun og námi barna með pví að beita umbun og refsingu. Í priðja lagi má skoða hvort sú sýn sé til staðar að umhverfi leikskóla styðji við gagnvirk samskipti og litið sé á börn sem borgara í samfélagi par sem lögð er áhersla á lýðræðislega pátttöku peirra (Dahlberg o.fl., 2007; Johansson, 2004; Prout og James, 2015). Í slíku leikskólasamfélagi er litið á börn sem samborgara, borin er virðing fyrir peim og peim treyst til að hafa áhrif í eigin námi.

Viðfangsefni pessarar rannsóknar tengist einna helst leikskólaumhverfi par sem eitt meginmarkmiðið er að bera virðingu fyrir tilfinningum og líðan barna. Í leikskólaumhverfinu er lögð áhersla á gagnvirk samskipti og litið á börn sem samborgara. Dar á líðan barna að vera í forgrunni fremur en að líta á hana sem truflun fyrir kerfið og dagsskipulagið (Sara Margrét Ólafsdóttir og Bryndís Garðarsdóttir, 2016). Við slíkar aðstæður er barninu og pörfum pess mætt á peim stað sem pað er hverju sinni. Að próa skráningar með áherslu á að fá fram sjónarmið barna getur pannig verið leið til að próa starfshætti sem styðja við velferð og vellíðan peirra. Áhersla er lögð á petta í Ađalnámskrá leikskóla (Mennta- og menningarmálaráđuneytið, 2012) og pví getur verið affarasælt að greina á hverju vellíðan barna byggist með pví að skoða hvernig stutt er við pátttöku barna í leikskólanum og greina með pví pátttöku barna.

\section{Mat á pátttöku barna}

Dátttaka barna í ákvarðanatöku, sem varðar peirra eigin tilveru, leiðir til bættrar líðunar og pau verða færari um að tjá skoðanir sínar (Bae, 2009). Bae (2009) lýsir pví í greininni „Children’s Right to Participate - Challenges in Everyday Interactions“ hvernig leikskólasamfélagið endurspeglar pjóðfélagið í pörfinni fyrir valdastrúktúr og reglur. Dótt leikskólastarf verði varla fullkomlega lýðræðislegt pá talar Bae um „lýðræðisleg augnablik“ sem fá að skína í gegn við og við í leik og starfi barnanna. Greinin byggist á rannsókn sem fram fór í leikskóla par sem safnað var gögnum með myndbandsupptökum úr daglegu starfi yfir heilan vetur. Myndböndin voru greind í samstarfi við leikskólastarfffólkið sem leitaði eftir pátttöku barna og lýðræðislegum augnablikum í starfinu. Rannsókninni var ætlað að lýsa pví hvernig Barnasáttmáli Sameinuðu pjóðanna (Samningur Sameinuðu bjóðanna um réttindi barnsins, 1989) getur virkað í daglegu starfi. Skýrt kemur fram í niðurstöðunum að pví meir sem börn eru studd til pátttöku á eigin forsendum peim mun betur líður peim (Bae, 2009). Svipaðar niðurstöður komu fram í rannsókn Söru Margrétar Ólafsdóttur (2013). Slík pátttaka er jafnframt í samræmi við Barnasáttmála Sameinuðu pjóðanna en parfnast jafnvel algjörrar endurhugsunar um hlutverk fullorðinna í starfi með börnum. Bae sér líka fyrir sér að rannsakendur purfi að taka nýjan pól í hæðina sem krefst pess að lýsa af nákvæmni hversdagslegri reynslu barnanna. Að hennar mati getur nákvæm skoðun 
á pátttöku barna varpað nýju ljósi á börn sem samborgara og hvernig pau nálgast umhverfið eftir fjölbreyttum og frumlegum leiðum.

Ef spurt er hvernig meta megi líðan barna út frá pví sem Bae (2009) segir pá liggur beint við að byrja á barninu og réttindum pess. Börn eiga rétt á pví að peim sé sýnd virðing, vilji peirra sé virtur og pau studd til að tjá sig í daglegu starfi. Að mati Bae er pessi réttur í hættu pegar val barna um leikefni og verkefni er gert að formlegu ferli par sem pau hafa í raun lítið um framboð viðfangsefna og valmöguleika að segja. Slíkt ferli geti litið út fyrir að vera lýðræðislegt en geti gefið börnum og öðrum ranga mynd af lýðræðislegri pátttöku í daglegu lífi. Dæmi um pað er pegar boðið er upp á svokallað „val“, par sem börn skiptast á um að velja leikstöðvar sem í boði eru en börnin, sem fá að velja síðust, hafa ekki úr mörgu að velja, jafnvel er eingöngu einn valkostur eftir, og purfa pví að „velja“ eitthvað sem pau hafa ekki áhuga á pá stundina.

Dau viðhorf skína í gegn í grein Bae (2009) að lýðræðisleg pátttaka barna í daglegu starfi auki ánægju peirra af dvölinni í leikskólanum. Ef pátttaka barna í starfinu er endurhugsuð út frá pví hvernig hana má efla og auka vellíðan barna pá setur Bae fram fjóra pætti: Í fyrsta lagi parf kennarinn að fylgja eftir frumkvæði barnsins, í öðru lagi að tjá sig og svara börnum af tilfinningu, í priðja lagi að hafa leikgleðina í fyrirrúmi hjá sjálfum sér og í fjórða lagi parf kennarinn að hafa pann hæfileika að geta skipt um sjónarhorn og horft frá sjónarhóli barnsins. Degar kennarinn iðkar pessa pætti ætti næmi hans gagnvart líðan og tilfinningum barna að aukast. T.d. getur kennarinn breytt samverustundum barnahópsins pegar hann sér að pátttaka barnanna er takmörkuð og börnin hafa ekki áhrif á pað sem gerist í pessum stundum. Pá ígrundar kennarinn stundirnar og próar leiðir til pess að auka pátttöku barna, ánægju peirra og starfsfólks. Með petta í huga hafa leikskólakennarar í ýmsum löndum skráð námssögur barna í peim tilgangi að safna gögnum um pað sem fram fer til að geta lesið í tjáningu barna, skoðað eigin aðferðir við að lesa í hana og styðja börn til áhrifa (Carr, 2001, 2011; Mayall, 2003).

Námssöguskráning, sem próuð var í Nýja-Sjálandi, er gerð með pað að markmiði að skrá pað sem börnin aðhafast með áherslu á styrkleika peirra og getu (Carr, 2001; Kristín Karlsdóttir og Bryndís Garðarsdóttir, 2010). Aðferðin var fyrst byggð á gildum ólíkra menningarhópa (New Zealand Ministy of Education, 1996; Carr og Lee, 2012) en samkvæmt peim er lögð áhersla á skoða pað sem fer fram í barnahópi, m.a. út frá tengslamyndun, vellíðan og sjálfsmynd barna, auk pess að leikskólakennarar ígrundi pær aðferðir sem notaðar eru til að styðja við nám barna (Carr, 2014). Framkvæmd skráninganna fer oftast fram í umhverfi sem börnin pekkja og skráð er með ýmsu móti, svo sem með skriflegri skráningu, ljósmyndum, myndbandsupptökum og hljóðupptökum. Hvatt er til pess að skráningar séu ígrundaðar af fullorðnum og börnum m.a. í peim tilgangi að nýta upplýsingarnar til að hvetja börn í pekkingarsköpun sinni. Í námssögumati er ekki eingöngu lögð áhersla á pekkingu og færni heldur er ferlið skoðað (e. assessment for learning) og ígrundað í kringum áhuga barna og pá færni sem börnin byggja upp í samvinnu við önnur börn og fullorðna (Carr og Lee, 2019).

Dessar skráningar geta verið gott tæki fyrir leikskólakennara sem vilja auka pátttöku leikskólabarna og getur skráningarferlið verið vettvangur fyrir pátttöku peirra (Heiða Mjöll Brynjarsdóttir, 2015). Áskoranir við skráningu námssagna geta verið annríki, erfiðleikar við að finna tíma til að skrá, ígrunda skráningarnar og miðla peim (Kristín Karlsdóttir og Anna Magnea Hreinsdóttir, 2015). Gagnrýni á notkun námssagna í mati á námi barna felur í sér að erfitt sé að sýna fram á gildi túlkana, túlkanir séu sjaldnast hlutlægar, skortur sé á leiðsögn í skráningarferlinu og erfiðleikar í pví að sýna fram á nám barna til lengri tíma (Blaiklock, 2008). Knauf (2017) komst að pví í rannsókn í 40 pýskum leikskólum að leikskólakennarar, sem gefa börnum tækifæri til að taka pátt í skráningarferlinu, eru á heildina litið lengra komnir í skráningaraðferðum. Hún segir víðtæka skráningu jafnvel ómögulega án pátttöku barna. Með víðtækri skráningu á hún við að leikur og starf barnsins í leikskólanum endurspeglist í skráningunum á fjölbreyttan og heildrænan hátt. Pátttaka barna í skráningarferlinu krefst pess að hlustað sé á börn og að peim séu gefin aukin tækifæri til pess að taka pátt í ákvörðunum sem varða pau (Lansdown, 2011). Dátttaka leiðir pannig til proska og betri ákvarðana. 


\section{Dátttakendur, vettvangur og aðferð}

Dessi rannsókn var samstarfsrannsókn sem miðaði að pví að starfsfólk í leikskóla og rannsakendur í háskóla ynnu saman við að próa aðferðir við mat á námi og vellíðan barna. Leitast var við að líta á alla pátttakendur sem sérfræðinga á sínu sviði pó peir sinntu ólíkum hlutverkum í leikskólanum og rannsókninni. Segja má að pátttakendur í leikskólanum hafi unnið samkvæmt starfendarannsóknarmódeli, pað er að peir tóku ákvarðanir um hvert peir vildu stefna, hverju og hvernig peir vildu breyta starfsháttum. Rannsóknin er kynnt sem samstarfsrannsókn par sem pátttakendur frá háskólanum, meistaranemi og háskólakennari, höfðu pað hlutverk að styðja pátttakendur í leikskólanum við framkvæmd rannsóknarinnar. Hlutverk háskólateymisins var enn fremur að skipuleggja sameiginlega fundi í leikskólunum fimm par sem fram fór umræða um mat, nám og vellíðan barna auk fræðslu um matsaðferðir sem pátttakendur í leikskólunum töldu sig geta nýtt sér í rannsókninni.

Pátttakendur í leikskólanum voru fimm starfsmenn á einni leikskóladeild, ásamt aðstoðarleikskólastjóra. Allir pátttakendurnir sex voru konur. Drjár peirra eru leikskólakennarar en hinar prjár störfuðu sem leiðbeinendur og höfðu ekki formlega menntun í faginu. Pátttakendum var öllum gefið dulnefni svo að ekki væri hægt að persónugreina pað sem fram kom í viðtölunum.

Dátttakendur voru eftirfarandi:

- Helga aðstoðarleikskólastjóri

- Margrét deildarstjóri og leikskólakennari

- Birna leikskólakennari

- Guðlaug leiðbeinandi

- Steina leiðbeinandi

- Sif leiðbeinandi

Markmið pátttakenda í leikskólanum var að skoða eigin viðhorf gagnvart námi og líðan barna með pví að próa aðferđir við að meta nám peirra og líðan. Börnin á deildinni voru 24 talsins og voru flest í kringum priggja ára aldur í upphafi vetrar.

Skipulag rannsóknarinnar var fólgið í pví að deildarstjóri leiddi próunarstarfið í leikskólanum ásamt meistaranema og sérfræðingi á Menntavísindasviði Háskóla Íslands sem eru höfundar pessarar greinar. Deir veittu jafnframt stuðning með reglulegum heimsóknum í leikskólann og umræðum um verkefnið. Deildarstjóri hélt fundi á tveggja til fjögurra vikna fresti með starfsmönnum deildarinnar til að fara yfir stöðuna og setja markmið um næstu skref. Degar líða tók á rannsóknina skrifaði starfsfólkið námssögur reglulega, ígrundaði og skipulagði starfið út frá peim.

Meistaranemi bar meginábyrgð á gagnaöflun sem fór aðallega fram með viðtölum við pátttakendur í leikskólanum um framkvæmd verkefnisins og snerist meðal annars um viðhorf peirra til barna, náms peirra og vellíðanar. Jafnframt héldu meistaranemi og pátttakendur í leikskólanum dagbækur og áttu bæði skipulögð og óformleg samtöl par sem rætt var um skráningarnar sjálfar og námssögurnar. Viðtöl voru tekin tvisvar við hvern pátttakanda. Fyrri viðtölin fóru fram haustið 2016 en seinni viðtölin vorið 2017. Auk pess hittist starfsfólk deildarinnar reglulega til að ræða námssögurnar, sem skrifaðar höfðu verið, og meta stöðu verkefnisins. Upptökur af viðtölum voru afrituð og greind. Greiningin fór pannig fram að gögn voru lesin ítrekað, pau flokkuð og loks voru greindir pættir sem annars vegar höfðu áhrif á ferli framkvæmdar verkefnisins og hins vegar vörpuðu ljósi á hugmyndir og reynslu pátttakenda í leikskólanum.

Áður en samstarfsrannsóknin hófst í pátttökuleikskólanum voru farnar tvær formlegar leiðir til að próa og meta nám barna, p.e. notkun persónumappna og SMTskólafærni (en SMT stendur fyrir ensku orðin School Management Training). SMTskólafærni er vinnuaðferð sem ætlað er að meta og móta hegðun barna með pví að setja jákvæðar skólareglur sem allir framfylgja. Félagsfærni var 
kennd og pjálfuð með markvissum hætti og jákvæð hegðun viðurkennd með hrósi. Viðbrögð við óæskilegri hegðun voru samræmd af kennurunum (Miðstöð РMTO foreldrafærni, e.d.). Reglulega voru námskeið fyrir nýja starfsmenn í SMTskólafærninni og upprifjunarnámskeið fyrir aðra. Lögð var áhersla á að hafa reglulegar skráningar um hegðunarfrávik og pví var fylgt eftir með svokölluðum skráningarvikum. Skráningarvikur voru einu sinni í mánuði, pá var áhersla lögð á að skrá alla neikvæða hegðun og átti bað að hvetja til skráninga. Sérkennslustjóri og deildarstjóri fóru yfir skráningarnar og greindu pá einstaklinga sem áttu við hegðunarerfiðleika að stríða, kortlögðu vandann og mátu hvaða aðferðum skyldi beitt til að takast á við hann. Skráningarnar lágu til grundvallar pví mati sem gert var á hegðun barna og viðbrögðum. Spyrja má hvernig pessi áhersla á viðbrögð við óæskilegri hegðun tengist skólanámskrá og peirri áherslu sem byggt er á í pví verkefni, sem hér er til umfjöllunar, pað er að ganga út frá styrkleikum barna, getu peirra og líðan.

Persónumöppurnar héldu hver um sig utan um verkefni hvers og eins barns og endurspegluðu sögu pess í leikskólanum. Í möppunum var áhersla lögð á barnið og að efla sjálfsmynd pess með jákvæðum skráningum um pað sem barnið fékkst við í leikskólanum. Pær áttu að efla tengsl leikskóla og heimilis með myndum og skráningum. Fastar skráningar voru í möppunni sem tengdust upphafi skólaárs, jólum, afmæli barnsins, sjálfsmyndum, listsköpun ásamt hópskráningum úr starfi leikskólans. Hverjum deildarstjóra var í sjálfsvald sett hvort aðrar skráningar færu í möppuna, hvort sem um var að ræða hópskráningar eða einstaklingsskráningar. Eitt af markmiðum pátttakenda í upphafi pessarar rannsóknar var að finna leiðir til að tengja persónumöppurnar við námssögurnar sem lagt var upp með að próa.

Unnið var út frá eftirfarandi rannsóknarspurningum:

- Hvernig aðferðir geta nýst til að meta nám og vellíðan barna í leikskóla?

- Hvaða hugmyndir höfðu pátttakendur í upphafi og í lok rannsóknar um mat á námi og vellíðan?

- Hvaða aðferðir voru próaðar í leikskólanum?

- Hvaða gildi hefur pátttaka í verkefninu um fjölbreyttar matsaðferðir fyrir starfffólk og leikskólastarf?

\section{Niðurstöður}

Niðurstöðurnar byggja á greiningu peirra gagna sem aflað var. Fyrst verður greint frá ferli framkvæmdarinnar, hvaða aðferðir voru próaðar og hver áhrif pátttökunnar í rannsókninni á starf deildarinnar virtust vera. Síðan verður greint frá pví hvernig hugmyndir pátttakenda um mat á námi og vellíðan barna voru í byrjun og hvernig pær próuðust yfir veturinn samfara pátttökunni í verkefninu. Loks verður greint frá pví hvernig starfsfólkið sagðist hafa breytt starfinu og eigin hugmyndum um mat á námi og líðan barna.

Í upphafi beindist áhugi pátttakenda að líðan barna í útiveru. Deir höfðu pá tilfinningu að sumum börnum pætti útiveran erfiður tími og vildu fylgjast með henni. Degar námssögur höfðu verið skrifaðar í nokkra mánuði komst starfsfólk deildarinnar og meistaraneminn að pví að nokkur börn komu aldrei fram í námssöguskráningum. Dar sást tækifæri til að skoða nánar hvað börnin aðhöfðust sem fangaði ekki athygli peirra sem skrifuðu námssögurnar. Pátttakendur ásamt meistaranema veltu fyrir sér hvernig pessum börnum liði og pað varð úr að starfsfólk deildarinnar ákvað að fylgjast sérstaklega með peim börnum sem voru utanveltu og tóku ekki sýnilegan pátt í samleik. Um miðjan veturinn færðist pví áherslan af skráningum í útiverunni á börnin sem komust ekki að í fyrstu námssögunum. Detta varð meðal annars til pess að barnahópnum var oftar markvisst skipt upp í minni hópa. Með pessu móti nýttust upplýsingar úr námssögunum til að gefa starfsfólkinu innsýn í líðan barna og pannig opnaðist ný leið til að skoða og meta vellíðan peirra. 


\section{Hugmyndir um mat á námi og vellíðan í upphafi}

Баð mat, sem framkvæmt var á deildinni fram að rannsókninni, var að mestu huglægt og var ekki skrád niður. Pátttakendur ræddu nám, proska og líðan barnanna pegar tóm gafst og í almennu spjalli um starfið og börnin. Foreldraviðtöl voru tekin einu sinni á ári og í peim var líðan barnanna rædd ásamt almennum framförum í proska. Persónumöppurnar voru notaðar til að skrásetja feril hvers barns í leikskólanum. SMTskólafærni var notuð til að stuðla að jákvæðum reglum á deildinni, til að skrá neikvæða hegðun og veita umbun eftir að barnahópurinn hafði í sameiningu safnað nógu mörgum hrósum. Starfsfólkið hrósaði börnunum með litlum brosspjöldum sem börnin hengdu upp á vegg. Pegar tilteknum fjölda brosspjalda var náð var öllum hópnum umbunað með tilbreytingu, t.d. náttfatadegi, strætóferð eða dótadegi (börn komu með leikföng að heiman).

Mismunandi viðhorf og hugmyndir komu í upphafi fram hjá pátttakendum á deildinni um mat á námi og líðan barna. Í daglegu starfi og skipulagi deildarinnar hafði ekki verið lögð áhersla á aðferðir við að skrá nám og líðan barnanna. Persónuleg reynsla, menntun, upplifun og mismikil meðvitund starfsfólks átti pví pátt í hvernig nám og proski barna voru metin. Viðhorf leikskólakennaranna endurspeglaði faglega pekkingu peirra og reynslu, pó peir lýstu persónulegum upplifunum og hugmyndum um aðferðir í starfi með börnum á mismunandi hátt. Dað sama má segja um leiðbeinendurna, sem lýstu í upphafi ólíkum hugmyndum en í lokin virtust fagleg sjónarmið peirra hafa styrkst.

\section{Viðhorf leikskólakennara í upphafi vetrar}

Áherslur í viðhorfum leikskólakennaranna voru um margt ólíkar, en höfðu pó tengingu við faglega reynslu peirra og pekkingu. Birna, leikskólakennari, vildi að börnin hefðu meira frelsi en Margrét, deildarstjóri, taldi best að skipulagið væri í föstum skorðum. Degar Birna talaði um frelsi átti hún við að börnin hefðu frelsi til að ákveða hvað pau vildu gera en Margrét taldi best að skipta hópnum niður með pað að markmiði að börnin kæmust í leik. Hún sagði: „Баð er svo gott að heyra „vinnuklið“ pegar öll börnin eru ánægð í leik og starfi.“”

Margrét sagðist ekki hugsa um pað sem börn endilega gætu heldur hvort ró væri í leik. Рað fannst henni vera mælikvarði á nám og líðan barna. Ef börn undu sér í leik, án hávaða, truflunar eða parfar á aðstoð frá fullorðnum pá var pað að hennar mati góðs viti. Hún vildi skapa góðar námsaðstæður fyrir börn en sagði: „,.. mér finnst starfið oft snúast mikið um að reyna að minnka „kaosið“ til að starfsfólki og börnum líði betur.“ Hún talaði um að stundum snerist starfið aðallega um að slökkva elda í samskiptum barnanna. Væntingar hennar til námssagna fólust í pví að námssögurnar gætu gefið meiri vitneskju um börnin og par með upplýsingar sem gætu nýst í mati. Dannig fannst henni að námssögur byggðu ekki á ,almennri tilfinningu leikskólakennarans fyrir börnunum heldur að pær gætu verið innsýn inn í getu og líðan barnsins“.

Birna, leikskólakennari, sagði í upphafi að hún vildi meta án inngripa, p.e.a.s. að standa utan við leik barnanna og fylgjast með án pess að bregðast strax við. Henni líkaði ekki pegar samstarfsfólk greip inn í samskipti barnanna og taldi pað ekki til bóta. Að hennar mati gæeti inngripið leitt til pess að raunveruleg tjáning barna væri heft. Einnig væru samskipti og tjáning barna oft stoppuð, til dæmis ef leikur var ærslafullur eða jafnvel til pess að láta börn pissa. Að hennar mati kæmi raunveruleg geta barnanna fram í óheftum leik og pví pyrfti að skoða leik peirra. Birna orðaði petta svona: „Баð parf ekki að meta hvað pau kunna, heldur hvað pau eru að gera ... skoða hvað er í gangi hjá barninu núna." Hún taldi að jafnframt pyrfti að styðja börn í pví að fylgja sínu áhugasviði og fylgjast svo með framförum barnanna, einblína pyrfti á nútíðina en taka fortíðina ekki of mikið með í reikninginn.

Birna nefndi dæmi um barn sem stæði á höndum pegar ætlast var til að pað sæti kyrrt. Hún taldi pað ekki merki um að barnið kynni ekki að sitja kyrrt heldur að pað hefði ekki haft áhuga á að fylgja reglum sem voru settar í viðkomandi kringumstæðum. Að mati Birnu sýndi pessi hegðun ekki eingöngu fram á nám barnsins eða líðan heldur ekki síður að barnið vildi ekki fylgja ákveðnum reglum í ákveðnum kringumstæðum. 


\section{Viðhorf leiðbeinenda í upphafi vetrar}

Viðhorf Steinu, leiðbeinanda, var nær viðhorfum leikskólakennaranna, sem pó voru orðuð á ólíkan hátt, en fólu í sér sýn á getu barna og líðan sem mikilvæg atriði. Hún lagði áherslu á að fá vitneskju um pað sem börn gætu gert og hún vildi að einblínt væri á pað í starfinu. Hún taldi pað vera mælikvarða á nám og líðan barna hvernig pau sýndu færni sína og ættu í samskiptum við önnur börn. Ef hún sá barn benda á príhyrning og segja: „Detta er príhyrningur“, pá fannst henni pað sýna fram á nám barnsins.

Fram kom pað sjónarmið að mat ætti fyrst og fremst að snúast um pann hluta leikskólastarfsins sem sneri að peim aðferðum sem starfsfólk beitti og hvernig mætti bæta pær. Petta kom fram hjá Guðlaugu, leiðbeinanda, sem hugsaði í upphafi um mat út á við, ekki út frá hverju barni. Hún taldi að meta pyrfti aðferðir leikskólans. Meta pyrfti starfið og finna út hvað gengur vel og gera svo meira af pví. Aðferðirnar, sem notaðar væru til að kenna börnunum, pyrfti einnig að meta, skrá hvað væri gert og hvernig pað virkaði. Hennar skoðun var að matið væri pannig á heildstæðu plani en ekki út frá hverju barni. Hennar hugmynd var að pað pyrfti að skrá hjá börnum ákveðna pætti og pær skráningar myndu haldast milli deilda pannig að hægt væri að fylgjast með frampróun hvers barns. Pannig myndi pekkingin fylgja barninu. Henni fannst mikilvægt að vinna skráningar pví annars væri hætt við að mörg atriði gleymdust.

Jafnframt kom fram sú hugmynd að mat hefði aðallega pann tilgang að bæta hegðun barna. Til dæmis kom fram hjá Sif, leiðbeinanda, að í leikskólastarfinu væru börnin metin svo að hægt væri að bæta hegðun peirra til pess að starfið gengi betur í leikskólanum. Hún talaði ekki um að meta nám barna eða líðan peirra. Hún leit ekki svo á að verið væri að skoða hegðun barna til að geta metið líðan peirra heldur taldi hún að litið væri á hegðun einungis í peim tilgangi að geta lagað hana, t.d. með pví að styðjast við broskallakerfi eða önnur viðbrögð sem styddu við rétta hegðun. Leiðbeinendurnir tjáðu viðhorf sín með mismunandi hætti, líklega að hluta til tengt persónulegri reynslu peirra, en jafnframt mátti greina áhrif frá skólastefnunni, t.d. pegar rætt var um hegðunarvanda barna.

\section{Ígrundun leið til að brúa ólíka sýn leikskólakennara og leiðbeinenda}

Í fyrri viðtölunum tjáđu leikskólakennararnir sjónarmið sem virtust tengd próun á fagmennsku peirra. Deir notuðu faglegan orðaforða, svo sem ígrundun, meðan leiðbeinendurnir tengdu umræðuefnið meira við eigin framkvæmd í starfinu eða annars konar viðhorf, svo sem bætta hegðun barna.

Við skoðun á pessari mismunandi sýn starfsfólks deildarinnar hefur komið í ljós hversu mikilvægt er að ígrunda pessar námssögur með samstarfsfólki, ekki einungis að skrá pær, og pannig deila peirri mynd sem námssögurnar gefa af námi og líðan barna. Detta má tengja við sögu sem Birna sagði um hóp stráka sem léku sér úti í ofurhetjuleik. Birna fylgdist með peim og taldi að í leiknum væru peir að æfa sig í pví sem peir porðu tæplega að gera, hún sagði: „Deir voru að æfa sig að vera hræddir." Birna vildi leyfa leiknum að próast en hann var stöðvaður af öðru starfsfólki. Til að varpa ljósi á pessar aðstæður og styrkja innsýn starfsfólks í pær taldi Birna að skráning námssagna um atvik sem petta gæti orðið gagnleg sem efni til ígrundunar fyrir nýja starfsmenn og fyrir faglegt samstarf einstaklinga í leikskólanum. Með pví móti fannst Birnu að pannig væri hægt að samstilla leikskólastarfið.

Segja má að ríkjandi viðhorfá deildinni hafi verið að nokkru leyti í samræmi við markmið pessarar samstarfsrannsóknar. Helga, aðstoðarleikskólastjóri, hafði mikinn áhuga á pessari rannsókn og sérstakan áhuga á líðan barnanna fremur en að hún legði sérstaka áherslu á að börn lærðu hefðbundið námsefni, svo sem lestur og stærðfræði. Hún sagði: „Đað er starf leikskólakennarans að meta líðanina ... svo kemur allt hitt í kjölfarið.“ Hún var sú eina sem talaði um öryggi barnanna. Dá átti hún ekki við líkamlegt öryggi heldur tilfinningalegt öryggi. Hún sagði pað lýsa líðan barnanna hversu mikið öryggi pau virtust finna í leikskólanum. Pað héldist í hendur. 
Að hennar mati væri öryggi í aðstæðum birtingarmynd sjálfsöryggis peirra. Helga leit svo á að stuðningur við öryggi barna væri eitt af meginatriðum pess sem fram ætti að fara í leikskóla, pví pyrfti starfsfólkið að ræða hvernig styðja mætti við öryggi barna.

Helga taldi mikilvægt að lesa í tjáningu barna og taka tillit til sjónarmiða peirra. Hún sagði að meta pyrfti hvað pau tjáðu hverju sinni, hér og nú. Hún nefndi dæmi um barn sem vildi ekki fara í kuldagalla til að fara í útiveru. Skoða pyrfti og ígrunda hvers vegna barnið vildi ekki fara í gallann og út. Ekki mætti einfaldlega ætla að barnið væri óhlýðið af pví að pað vildi ekki fara í gallann, heldur pyrfti að horfa á ástæður að baki tjáningu barnsins. Reyna pyrfti að fá fram ástæður fyrir pví að barnið mótmælti pví að fara í flíkina. Mögulegar ástæður gætu verið að barnið vildi ekki láta stjórna sér, pað vildi ekki fara út eða að pað vildi ekki hætta pví sem pað var að gera. Helga orðaði petta svona: „Баð má ekki afskrifa börn út af hegðun peirra, pað er alltaf eitthvað sem býr að baki.“ Hún sagði að leikskólastarfsfólk yrði að gera sér grein fyrir pví að börn tjáðu sig ekki eingöngu með orðum heldur einnig með hegðun sinni. Deir sem ynnu með börnum pyrftu sífellt að skoða og ígrunda hvort pað væri eitthvað í starfinu sem ylli peim vanlíðan.

Skoðun Helgu, pegar hún ræddi um mat, var sú að meta pyrfti heildstætt líðan barnsins yfir allan daginn, alveg frá pví að pað mætti og par til í lok dagsins. Vanlíðan barns gæti endurspeglast í pví að kannski hæfist dagurinn á pví að barnið vildi ekki fara úr útifötunum, svo lemdi pað einhvern, svo kæmu fram fleiri pættir par sem barnið hegðaði sér undarlega og loks vildi pað ekki vera úti аð leika. Skoða pyrfti hvort petta gæti mögulega allt verið tengt. Helga sagði: „Dessi tjáning gæti verið svo margt ... ákall eftir athygli ... að barninu pyki erfitt að vera í hópi ... eða að eitthvað hafi gerst heima fyrir." Að mati Helgu snerist petta um að lesa í tjáningu barnsins, hvort hún gæti pýtt að barnið upplifði eitthvað óöryggi sem birtist á ýmsa vegu yfir allan daginn. Til að fá pessa yfirsýn um daglega líðan barns pyrftu starfsmenn að miðla upplýsingum sín á milli.

Samhljómur var í upplifun pátttakenda í upphafi vetrar í pá veru að skráningar væru ekki nægar í leikskólastarfinu. Deim fannst að talað væri um hlutina á óskipulegan hátt pegar fólk hittist af tilviljun á vinnustaðnum og ekki væru notaðar aðferðir til að skrá, ígrunda og fjalla skipulega um pað sem skráð var. Allir töluðu peir um að hægt væri að komast að ýmsu um börnin með pví að fylgjast með leik peirra. Deir höfðu allir ólíka skoðun á inngripi í leik barnanna. Einn vildi leyfa leiknum að próast án inngripa en annar vildi stöðva slæma hegðun í leik fljótt. Nokkrir voru uppteknir af pví að tala um hegðun barnanna, að henni pyrfti að breyta ef pörf væri á. Allir minntust peir á einn eða annan hátt á að lítill tími væri til að vinna að skráningum og til ígrundunar um pær en vonuðust til að fá tíma til að próa sig áfram með pátttöku í rannsókninni. Guðlaug, leiðbeinandi, nefndi „spennu“ fyrir rannsókninni pví hún hafði upplifað að sjá eitthvað áhugavert í leik barna en ekki haft tíma til að skrá pað. Hún sagði: „Darna var eitthvað í gangi sem kannski hefði verið hægt að læra af ... pað var eitthvað meira parna.“ Hún vildi læra meira um pað hvernig hægt væri að meta nám barnanna og líðan. Sif upplifði svipað pegar hún skrifaði fyrstu námssöguna sína. Hún upplifði fallegan samleik nokkurra barna, varð uppnumin af pví hversu fær pau voru í samskiptum og hversu mikil samhygð bjó innra með peim. Hún sagði að parna hefðu pau verið að vinna úr ýmsu sem pau hefðu heyrt og séð og notað pað í leik.

\section{Dróun hugmynda og aðferða}

Á reglulegum fundum deildarinnar, sem haldnir voru á tveggja til fjögurra vikna fresti, fór fram nánari samræða um skráningar og verkefnið í heild sinni. Dessir fundir reyndust mikilvægir fyrir pátttakendur til að ræða og ígrunda pað sem fram fór á deildinni. Nefnt var í seinni viðtölunum að fundirnir hefðu jafnvel mátt vera tíðari en einnig kom fram að á fundunum virtist skilningur á börnum og aðstæðum peirra aukast pegar skráningarnar voru ræddar nánar.

Degar í ljós kom að sum börn rötuðu síður í skráningar pátttakendanna var ræett hvort sum börn birtust 1 mörgum sögum vegna pess að pau ættu auðveldara með að tjá sig með orðum og væru 
jafnvel skapandi í leik. Svo virtist sem pau börn á deildinni, sem voru ekki með eins góðan orðaforða og önnur börn og/eða ekki eins fær í annars konar tjáningu, yrðu út undan í skráningu námssagnanna. Petta var tekið til frekari umræðu og ígrundunar. Rætt var um hvað pessi börn hefðu fyrir stafni, hver væri proski peirra og hvernig peim liði. Tekin var ákvörðun um að fylgjast með börnum sem við nánari skoðun virtust vera svolítið utanveltu í barnahópnum, en pað kom sérstaklega fram pegar börnin höfðu frjálst val um viðfangsefni.

Degar pátttakendur í leikskólanum höfðu fylgst með nokkrum börnum, sem höfðu ekki áður birst í námssögum, komust peir að pví að sum börn á deildinni virtust ekki taka pátt í leik af einhverjum ástæðum. Sömu börn virtust ekki eiga nána vini og peim almennt ekki líða vel í leikskólanum. Skoðað var hvernig hægt væri að styðja pessi börn. Í framhaldi af bví var ákveðið að skipta börnunum í minni hópa, helmingur hópsins færi út að leika og hinn helmingurinn væri inni að leika. Með pessum hætti gat starfsfólkið hugað betur að pví sem fram fór í barnahópnum og gefið sig meira að leik peirra, auk pess sem minni hávaði varð pegar færri börn voru í sama rými. Starfsfólkið náði betri tengslum við börnin, pau sem áður höfðu verið utanveltu byrjuðu að opna sig meira og starfsfólkið sagðist sjá bætta líðan hjá peim. Starfsfólkið hefði trauðla séð líðanina hjá börnunum sem voru utanveltu ef pað hefði ekki fylgst með börnunum og skráð pað sem fyrir augu bar. Flestir pátttakendurnir nefndu í síðari viðtölunum að skráningarnar hefðu hjálpað peim að sjá betur líðan barnanna.

Námssögurnar, sem próaðar voru yfir veturinn, voru líkar peim sem lagt er upp með samkvæmt námssöguaðferðinni. Sögurnar voru í byrjun mjög langar, allt að einni fullskrifaðri A4-blaðsíðu. Með tímanum styttust sögurnar og urðu hnitmiðaðri. Sögurnar innihéldu flestar ljósmyndir og einnig var sagt í stuttu máli frá pví sem eitt barn eða fleiri gerðu í leik sínum. Starfsfólk deildarinnar útbjó í sameiningu greiningarblað par sem helstu proskapættir voru útlistaðir og var geta og líðan barnanna greind út frá pví. Detta ferli voru pátttakendur í leikskólanum ánægðir með.

\section{Breytt viðhorf og nýjar aðferðir við skráningu}

Í lok vetrar sögðust allir, bæði leikskólakennararnir og leiðbeinendurnir, hafa lært af pví að skrá námssögur. Dað sem leikskólakennararnir tjáđu sig um bar gjarnan vott um að peir störfuðu í fagi sem peir höfðu menntað sig í. Eftir veturinn fannst Margréti hún hafa fengið tækifæri til að virkja pað sem hún hafði lært í gegnum tíðina. Henni fannst hún hafa fengið tæki til að meta nám og líðan barnanna. Henni fannst petta hafa skerpt fagvitundina hjá sér og öðrum.

Segja má að allir pátttakendur í leikskólanum hafi öðlast betri skilning á pví sem fram fór í barnahópnum, að sýn peirra gagnvart börnum hafi breyst og peir hafi jafnvel nálgast sjónarhorn barnanna betur. Meðal annars fannst Birnu, leikskólakennara, hún hafa fengið betri innsýn í sjónarmið barnanna. Henni fannst hún hafa aukið skilning sinn á bví sem fram fór hjá börnunum og gerði pað starf hennar markvissara. Henni fannst pátttaka í verkefninu hafa opnað augu allra á deildinni, sérstaklega á meðal leiðbeinendanna. Birnu fannst starfsfólk deildarinnar sjá ágreining milli barnanna með öðrum hætti en áður. Henni fannst starfsfólkið geta greint ágreininginn betur og reynt að vinna úr honum í stað pess að láta hann pirra sig eða að stimpla börn sem ómöguleg. Hún sagði námssögurnar nýtast við að hjálpa starfsfólkinu að ,vera vakandi einmitt fyrir pví hvað er í gangi hjá börnunum og horfa á hvernig peim líður; horfa á hvort pau eru að læra eitthvað. Eru pau að gera eitthvað sem pau hafa virkilega áhuga á? Ekki bara setja pau í púsl við bord“.

Fram kom í máli leiðbeinendanna sjálfra að peir höfðu allir lært af pátttöku í verkefninu pó að peir lýstu pví á ólíkan hátt. Steina sagðist vera opnari eftir veturinn og að hún fylgdist öðruvísi með börnunum. Hún nefndi nokkrum sinnum í seinna viðtalinu líðan barnanna og að hún liti nú á hana öðrum augum. Henni fannst námssöguaðferðin bjóða upp á að vera „opin fyrir hverjum einstaklingi fyrir sig og styðja við pá hæfileika sem hann hefur og passa upp á að börnunum líði vel ... passa upp á hvern einstakling og styðja hann. Раð er enginn eins og allir með sérparfir". 
Undir lok rannsóknarinnar kom einnig fram breytt sjónarmið hjá Steinu. Hún taldi pá að hegðun væri ekki eitthvað sem pyrfti að lagfæra, mikilvægara væri að hlúa að vellíðan barnanna.

Með pessu móti höfðu leiðbeinendurnir próað faglega hugsun sína. Guðlaug sagði til dæmis að verkefnið hefði mótað hana mikið um veturinn og próað fagvitund hennar. Sagðist hún hafa orðið meðvitaðri um líðan barna og gagnrýnni á störf sín. Hún taldi að námssöguaðferðin virkaði mjög vel með pví starfi sem unnið var á deildinni. Hún upplifði að pað að búa til sögur og reyna að komast inn í hugarheim barnsins í leiknum hjálpaði henni að skilja barnið betur. Henni fannst pað sem hún hafði lært um veturinn vera mjög mikilvægt og og sagði: „Баð parf að fræða allt nýtt starfsfólk um leikinn og hvað hægt er að læra um börn í gegnum hann ... um líðan peirra og nám.“" Pannig fannst henni að skráningarnar opnuðu henni nýjar dyr inn í heim barnanna.

Leiðbeinendurnir urðu pannig meðvitaðir um hugmyndir barnanna og hvernig mætti styðja börnin við að próa pær. Sif, leiðbeinandi, nefndi strax í upphafi seinna viðtals líðan barna. Hún sagðist hafa hugsað um hugarástand barnanna og hvar pau væru stödd í getu og proska. Hún taldi sig vera farna að sjá proska barnanna í gegnum sögurnar og að pær sýndu henni hvar væri hægt að styðja við proska og leik barnanna. Eftir að hún hóf að skrá námssögur gat hún hjálpað barni, sem hún sá að lék sér ekki, og fundið viðfangsefni við hæfi pess. Pegar hún fylgdist með einstaka barni î leik sá hún að sum barnanna, sem hún hélt að væru í leik, gengu bara í hringi og komust ekki inn í leik með öðrum börnum. Hún sagðist horfa á leikinn og sjá hvernig börnunum liði, lesa í tjáningu sem hún hefði ekki tekið eftir fyrr. Hún nefndi sem dæmi pegar hún fylgdist með barni: „,.. pað kom samt út eins og hún væri í leik ... hún var bara að labba eitthvað um í salnum ... ef maður væri ekki búinn að fylgjast með pá myndi maður halda að hún væri búin að vera í leik." Pannig upplifði Sif að vinnan við petta verkefni hefði hjálpað henni að setja sig í spor barnanna, að horfa á aðstæður út frá peirra sjónarhorni og reyna að meta hvernig peim liði. Hún sagðist sjá betur út frá skráningunum pau börn sem voru ekki pátttakendur í leik með öðrum börnum. Að mati Sifjar var leikurinn „,ekki lengur eitthvað sem börn voru bara sett î“ heldur sá hún leikinn sem leið til að skilja betur líðan barnanna.

Dessi innsýn, sem varð sterkari hjá starfsmannahópnum í heild sinni, varð svo til pess að skipulagi deildarinnar var breytt. Pátttakendur töluðu allir um að vinnan við rannsóknina hefði hjálpað peim við að sjá pörf fyrir skipulagsbreytingar. Peir sáu að pað hæfði ekki sumum börnum að vera saman og skipulögðu pað pví pannig að pau börn, sem peim fannst ekki geta verið saman, voru sett í sinn hvorn hópinn og hóparnir ekki látnir skarast nema sjaldan yfir daginn. Dað jók vinnufriðinn auk pess sem börnin virtust ná betur saman pegar pau hittust í styttri tíma. Sumir pátttakendanna sáu samskipti barna á annan hátt eftir að peir hófu að skrá námssögur. Fyrsta upplifun Guðlaugar af pví að skrá námssögur var sú að hún kæmi auga á fleira en hún hefði séð í fyrstu. Allir pátttakendur lýstu reynslu sinni eftir veturinn pannig að skráning námssagna og ígrundun peirra hefði orðið til pess að auðvelda mat á námi og líðan barna. Sumir peirra tjáđu pá skoðun sína að skráning námssagnanna hefði hjálpað peim að sinna betur pví mati sem Aðalnámskrá leikskóla kveður á um að leikskólar skuli inna af hendi.

\section{Markvissari vitund um nám og líðan barna}

Dátttaka starfsfólksins í rannsókninni opnaði augu flestra fyrir pví hversu gagnleg skráning námssagna gæti reynst til að gefa páttum sem varða nám og líðan barna betur gaum. Í viðtölunum kom pó fram að pátttakendur höfðu mismunandi sýn á hvernig mat ætti að fara fram. Birna orðaði pað pannig að ,,pegar mat fer fram parf að stoppa til að hugsa hvað við sjáum í tjáningu barnsins“. Að hennar mati væri hægt að ígrunda sögurnar og greina ýmsa færni hjá börnunum, svo sem félagsfærni eða grófhreyfingar, í stað pess að velta fyrir sér hegðunarvandamálum. Dannig væri hægt að sjá hjá börnunum hvort pau fyndu fyrir öryggi í eigin líkama og í félagslegum aðstæðum. Við nánari ígrundun á pví sem fram fór töldu pátttakendur sig geta orðið meðvitaðir um líðan barnanna og jafnvel geta séð jákvæða hluti í neikvæðri hegðun. Með pví móti gætu peir stutt börnin í að öðlast sjálfstraust og styrk til að upplifa sig sem getumikla og færa einstaklinga. 
Í lok vetrar töldu pátttakendurnir sig vera orðna meðvitaðri um nám og líðan barnanna yfir veturinn. Deim fannst peir hafa pjálfast 1 að greina betur hvað var í gangi í leik barnanna og pannig væri auðveldara að grípa inn í aðstæður. Pátttakendur tóku jafnframt eftir börnum sem tengdust ekki öðrum börnum og virtust ekki una sér í leik. Degar leið á veturinn urðu peir áræðnari í að mæta hverju barni par sem pað var hverju sinni. Í gögnum rannsóknarinnar má oft greina petta, líkt og sjá má í tveimur dæmum. Annars vegar birtist petta pegar Guðlaug fylgdist með stelpu í leik og kom auga á hversu mikið frumkvæði og sjálfstraust hún sýndi. Dar áttaði Guðlaug sig á pví - sem var ekki ljóst í hennar huga áður - hversu fær stelpan var, jafnvel í samskiptum við eldri börn. Annað dæmi átti sér stað par sem önnur stelpa lék sér í salnum og Sif fylgdist með henni i 20 mínútur. Sif skrifaði hjá sér: „Ef ég hefði ekki fylgst með henni hefði litið út eins og hún hefði verið í miklum leik pví að hún var á mikilli hreyfingu." Skráningin sýndi að hún var dugleg að fara um og hafa ofan af fyrir sér en hún hafði ekki samskipti við önnur börn. Pátttakendur áttuðu sig á pví að prátt fyrir að sum börn virtust í fljótu bragði vera að leika sér og jafnvel í samleik við önnur börn pá gat komið fram við nánari skoðun á skráningum að pau hefðu ekki verið í leik og virtust vera út undan í hópnum. Deir gerðu átak í að reyna að fylgjast með pessum börnum og styðja pau til pátttöku í leik með öðrum börnum. Рað gerðu peir með pví að leika við pau og fara með peim inn í leik annarra barna.

Fram kemur í gögnum rannsóknarinnar umræða um að tíma skorti fyrir námssöguskráningar í leikskólastarfið sem er afar krefjandi. Í daglegu starfi er mikið um að vera, starfsfólk hefur í mörg horn að líta og pví ekki alltaf tækifæri til að taka eftir og lesa í ólíka tjáningu barnanna. Dátttakendur töluðu um að leikskólakennarar pyrftu tíma til að spjalla um verkefni dagsins, hvernig börnunum liði, hverjar væru áskoranirnar hverju sinni og auk pess að upplýsa nýja starfsmenn og leiðbeinendur um pað sem fram kæmi í skráningum um börnin. Í fyrri viðtölunum kom fram mismunandi sýn pátttakendanna á nám og líðan barna en pegar leið á veturinn urðu vinnubrögð pátttakenda samræmdari. Deir fóru að vinna meira sem ein heild með hagsmuni barnanna að leiðarljósi. Undir lok vetrarins má lesa í rannsóknardagbók meistaranema: „Ðað er mín upplifun að fagmennska peirra [pátttakendanna] hafi aukist. Pær eru komnar með meiri orðaforða til að tala um börnin og pær eru orðnar betri og fljótari til að ígrunda börnin og eigin starfshætti.“ Starfsfólkið hafði orðið meðvitaðra og par með varð samstarf pess meira gefandi. Áskoranirnar í leikskólastarfinu voru orðnar að verkefnum sem pátttakendur tókust á við samhentir.

\section{Umræður}

Tilgangur samstarfsrannsóknarinnar, sem pessi grein fjallar um, var að starfsfólk leikskóladeildarinnar, sem tók pátt í rannsókninni, próaði aðferđir við mat á námi og vellíðan barnahópsins. Fram kom í upphafi að markmið pátttakenda með starfi sínu væri að börnunum liði vel og pað væri góð tilfinning á deildinni. Dátttakendur sýndu áhuga á pví að mæta betur kröfum Aðalnámskrár leikskóla um próun aðferða til að meta nám og líðan barna. Upplifun starfsfólks deildarinnar í upphafi var að skráningar væru í lágmarki og peim pyrfti að fjölga til að betri mynd fengist af námi og líðan barnanna.

Með innleiðingu námssagna varð vitundarvakning á meðal starfsfólks deildarinnar gagnvart pví sem fram fór í leik barna og hvernig mátti greina betur sjónarmið peirra. Í upphafi samstarfsrannsóknar mátti greina að pað sem pátttakendum pótti skipta máli í starfi deildarinnar var að börnin hegðuðu sér vel og að grípa pyrfti inn í pegar eitthvað færi úrskeiðis á milli barnanna. Í lok rannsóknarinnar kom fram að pátttakendur höfðu próað með sér ný viðhorf. Námssöguskráningarnar gerðu flestum pátttakendum kleift að greina sjónarmið barnanna og að lesa betur í líðan og áhuga peirra, sérstaklega virtust leiðbeinendurnir auka innsýn sína í líðan barna. Detta er í samræmi við pað sem kom fram í rannsókn Kristínar Karlsdóttur og Bryndísar Garðarsdóttur (2008) um áhrif skráninga á sýn leikskólakennara og leiðbeinenda á börn.

Dátttakendur tileinkuðu sér að fylgjast með leik barnanna, skrá og ígrunda hvaða nám færi fram hjá börnunum og hvernig líðan peirra birtist. Peir komust jafnframt að pví að námssögurnar 
reyndust nýtast vel með öðrum skráningum, sem gerðar voru í leikskólanum, og tengjast persónumöppunum. Deim fannst henta vel að setja námssögurnar inn í persónumöppurnar sem myndu síðar fylgja barninu yfir á næstu deild. Með pví væri auðveldara að fylgjast með námi barnsins, getu pess og líðan. Persónumöppunum er einmitt ætlað að endurspegla hið jákvæða hjá barninu en pað líkist pví sem er meginmarkmið í námssöguskráningum - að hafa styrkleika barna í forgrunni (Carr, 2001; Kristín Karlsdóttir og Bryndís Garðarsdóttir, 2010).

Hugmyndir og sjónarmið pátttakendanna um börn, proska peirra og hlutverk virðast tengjast pví hversu mikil hugsun og ígrundun hefur farið fram hjá hverjum og einum. Í fræðilega kaflanum var rætt um viðhorf til barna, pátttöku peirra, velferð og vellíðan. Degar starfsfólk deildarinnar ígrundaði starfshætti sína og hugmyndir um hvernig nám og líðan barna væru metin pá fór af stað ferli sem skilaði sér í að allir pátttakendur töluðu um að meiri tenging hefði orðið við nám barnanna, líðan peirra og hugðarefni (Bae, 2009). Leikskólakennararnir styrktust í fagmennsku sinni, pví sem peir höfðu áđur lært og prófað, orðræða peirra fól í sér fagorð og umræða peirra endurspeglaði skilning á markmiðum og tilgangi skráninga eins og kom fram í rannsókn Heiðu Mjallar Brynjarsdóttur (2015). Auk pess kom fram í orðum Guðlaugar mikilvægi pess að meta starfið og gæði pess sem er í samræmi við pau viðhorf og aðferðir sem hafa verið stunduð í sænskum leikskólum (Broström, Jóhanna Einarsdóttir og Pramling Samuelsson, 2018; Jóhanna Einarsdóttir, 2017).

Leiðbeinendurnir prír töluðu um hversu mikið peir hefðu lært yfir veturinn. Deir öðluðust aukna vitund um nám og líðan barnanna. Deir próuðust frá pví að hugsa um hegðun barnanna sem eitthvað sem pyrfti að móta og laga (Miðstöð PMTO foreldrafærni, e.d.) yfir í að ígrunda hvaða nám hefði farið fram hjá börnunum í mismunandi kringumstæðum. Pannig jókst virðing peirra fyrir tilfinningum og líðan barnanna og peir sáu börnin sem samborgara sem hægt væri að leiðbeina (Bae, 2009). Sú sýn, sem fram kom hjá Helgu, aðstoðarleikskólastjóra, nálgaðist pað аð verða að veruleika, p.e. að börnin upplifðu tilfinningalegt öryggi í leikskólanum (Bae, 2009; Sara Margrét Ólafsdóttir, 2013).

Óljóst er hvernig hægt er að tengja námssöguskráningar, par sem áhersla er á nám og líðan barna, við SMT hugmyndafræðina. Í pessu tvennu má greina andstæð grundvallarviðhorf. Annars vegar eru í markmiðum námssöguskráninga styrkleikar barna í forgrunni en hins vegar er í upphafi SMT horft til óæskilegrar hegðunar peirra. Í viðtölunum kom ekki fram umræða um SMT en einn leiðbeinandinn talaði í fyrra viðtalinu eins og hún væri undir áhrifum frá SMT. Hún notaði t.d. orðalag eins og að bæta og lagfæra hegðun. Notkun leikskólans á SMT byggist á pví að skrá óæskilega hegðun barna og reyna að setja jákvæðar reglur um hvernig brugðist skuli við henni. Námssögurnar hafa getu og hæfni barna í forgrunni og pví spurning hvort meiri upplýsingar um styrkleika barna gætu nýst í leit að leiðum til að styðja við jákvæða hegðun peirra. SMT er verkfæri sem að mestu er notað á forsendum kennara. Pátttaka barna er einungis fólgin í pví að velja umbun pegar skilyrðum um jákvæða hegðun er mætt af hálfu barnsins. Ef skráning á að vera á forsendum barna purfa pau að taka pátt í ákvarðanatöku og skráningarferlinu (Knauf, 2017). Reynsla pátttakenda af rannsókninni, sem fjallað er um í pessari grein, var að skráning námssagna og ígrundun á peim hefði haft jákvæð áhrif á hegðun barnanna og starf deildarinnar. Dví er pað áhugavert áframhaldandi rannsóknarefni hvort hægt sé að samræma námssöguskráningu og SMT hugmyndafræðina eða hvort námssöguskráningar geti komið í staðinn fyrir SMT og pannig byggt upp reglur á jákvæðum nótum sem fela í sér sjónarmið barna.

Námssöguaðferðin var notuð til að próa skráningar sem veittu innsýn í hugarheim barnanna og nýttust sem viðbót inn í persónumöppurnar sem fylgja börnunum í gegnum leikskólagöngu peirra. Dátttakendur voru spenntir yfir pví að hafa próað nýjar leiðir til að fylgjast með námi og líðan barnanna með pví að skrá námssögur. Leikskólakennurunum á deildinni fannst peir hafa notað svipaðar aðferðir í gegnum tíðina en tóku pessari aðferð fagnandi og tileinkuðu sér gerð námssagna. Leiðbeinendunum, sem kynntust í fyrsta sinn pessari aðferð, kom skemmtilega á óvart hversu mikla innsýn peir öðluðust inn í pað sem fram fór í leik barna. Deir töluðu um að petta 
væri aðferð sem peir myndu tileinka sér í áframhaldandi starfi sínu. Dátttakendurnir ýjuðu sjálfir að pví að peir hefðu mátt standa sig betur og gera meira en tilfinningin hjá greinarhöfundum eftir rannsóknarveturinn og úrvinnsluna er að pátttakan í samstarfsrannsókninni hafi haft djúpstæðáhrif á pátttakendur og starf deildarinnar sem muni skila sér í faglegra starfi og breyttum hugmyndum um nám og líðan barna. Mikilvægi rannsóknarinnar er sérstaklega fólgið í gildi hennar fyrir hina ófaglærðu starfsmenn, leiðbeinendurna. Deir tóku virkan pátt í öllu ferlinu og var hlustað á sjónarmið peirra til jafns við aðra. Leiðbeinendurnir öðluðust nýja sýn inn í leikskólastarfið og par með má ætla að áhugi peirra hafi eflst við að bæta eigin vinnubrögð. Áhugi peirra á að afla sér frekari menntunar jókst, bæði hvað varðar pað að hafa áhuga fyrir að fara í leikskólakennaranám og með pví að sækja námskeið um starf með börnum í leikskóla. Samstarfsrannsókn sem pessi, par sem lagt er upp með jafna pátttöku leiðbeinenda og leikskólakennara, virðist góð aðferð til að gefa leiðbeinendum innsýn í faglega starfshætti í leikskóla og auka áhuga á starfinu sem slíku.

Degar horft er til framtíðar og velt fyrir sér hver áhrif pátttökunnar virðast vera pá kemur einkum tvennt upp í hugann. Í fyrsta lagi er pað mikilvægi pess að leikskólar taki pátt í verkefnum sem fela í sér ígrundun á eigin starfsháttum. Skráningarnar kölluðu á ígrundun um pað sem fram fór í leikskólanum; leiðbeinendurnir nutu góðs af henni pannig að pátttaka í verkefninu efldi pá í starfi par sem peir próuðu hugmyndir sínar og viðhorf um nám og börn. Samræður og ígrundun starfsfólksins leiddi til pess að flestir fóru að sjá börnin, samskipti við pau og peirra á milli á annan hátt en áður, t.d. með vellíðan peirra í huga, eða að reyna að skilja betur ástæðurnar fyrir athöfnum barnanna. Detta er í takt við pað sem Demahefti um námsmat í leikskólum (Mennta- og menningarmálaráđuneytið, 2013) leggur upp með, p.e. að ígrunda eigið starf út frá skráningum í peim tilgangi að meta nám og líðan barna með fjölbreyttum hætti.

Í öđru lagi pá fékk barnahópurinn öđruvísi athygli en hann hafði áður fengið. Starfsfólkið varð meðvitaðra um öll börnin og pegar leið á veturinn kom í ljós að sumum börnum leið ekki eins vel og hafði verið haldið. Pegar pátttakendur komust að pví var peim brugðið og beindu athyglinni að pessum börnum. Pað jók starfsánægju peirra að finna að börnunum leið betur (Kristín Karlsdóttir og Anna Magnea Hreinsdóttir, 2015). Jafnframt gerðu pátttakendur skipulagsbreytingar á deildinni, léttu með pví álagið, bættu starfsumhverfið sem varð rólegra og skapaði meira rými fyrir börnin. Námssöguskráningarnar veittu peim nýja sýn inn í heim barnanna sem lýsir sér vel í orðum Guðlaugar pegar hún sagði að pað væri eitthvað meira parna. Degar skráningar eru ígrundaðar kemur margt í ljós sem starfsfólk tekur ekki eftir í dagsins önn. Skráningarnar geta orðið innihaldsríkari og skilað meiri árangri pegar unnið er meira með pær (Carr og Lee, 2019; Knauf, 2017). Dví er mikilvægt að halda áfram með pað góða starf sem unnið var í samstarfsrannsókninni, fara dýpra í skráningarnar og tengja foreldra og börn meira inn í skráningarferlið.

\section{Lokaorð}

Niðurstöður pessa hluta samstarfsrannsóknarinnar benda til pess að skráningar námssagna veiti leikskólakennurum og leiðbeinendum dýpri innsýn í sjónarmið barna og par af leiðandi hvernig próa má leikskólastarfið með hliðsjón af áhuga og styrkleika peirra. Tvennt stóð upp úr í peim leikskóla sem hér er fjallað um, en pað tengist annars vegar bví að námssöguskráningarnar nýttust leiðbeinendum sérlega vel, pað er peim sem ekki höfðu lokið leikskólakennaramenntun. Með pví móti má ætla að skráningar geti orðið nokkurs konar endurmenntun fyrir leiðbeinendur og geti pannig stuðlað að faglegri starfsháttum í leikskólum. Hins vegar var áhugavert hvernig leikskólakennarar og leiðbeinendur hófu að einbeita sér sérstaklega að vellíðan barnanna, leitast var við að öllum börnum væri mætt, ekki síður peim sem alla jafna kölluðu ekki á athygli og voru í upphafi „ósýnileg“ í skráningum. Í ljós kom að leikskólakennurum og leiðbeinendum fannst pau hafa full litla vitneskju um áhuga peirra, parfir og líðan. Nánari námssöguskráning og athygli beindist að pví að afla meiri upplýsinga um börnin, sem gerði leikskólastarfið betra fyrir öll börn. 


\section{"There was something more in this": Assessing children's learning and focusing on their well-being}

This article describes a collaborative action research project performed in a preschool in one of the neighbouring municipalities of Reykjavík. Participants were five staff members in one classroom and a school director, along with the authors of this article; a master's student; and an associate professor at the University of Iceland. The aim of the study was to explore the assessment methods used in one preschool and develop methods to assess children's well-being and learning in line with the National Curriculum Guide. Three participants were qualified preschool teachers and three were not educated in the field of preschool practice. This was a three-year project, the main data gathering taking place in one school year, from September 2016 to May 2017.

The data comprised interviews, research diaries and documentation and was analysed with the purpose of showing the processes of collaborative action research. A further aim was to explore children's involvement in play and other activities and aspects of the teachers' working methods by reflecting on their views and actions in the preschool. The objective was to gain answers about what kind of methods would work to assess children's learning and well-being; whether or how the participants' views had changed during the research period; what assessment methods were developed in the preschool; and the value for the teachers of taking part in collaborative action research seeking diverse assessment methods.

Before the research started, methods used in the preschool to assess the children's education were mainly influenced by personal folders made for all children. Specimens of children's artwork and photos from their activities in the preschool are collected in the personal folder which is supposed to show the progress of the child's thinking and abilities, and also document major events in the child's life; birthdays, holidays and special events at the preschool. Another formal method used in the preschool was the SMT (School Management Training) which aims to support children's social competence by tackling inappropriate behaviour and encouraging positive behaviour. The SMT ideology presents positive enforcement of positive rules. Negative behaviour is documented and the information used to change its patterns is enforced by the same methods used by all staff.

The data describes the views of the participants in the beginning and the end of the school year, regarding children's learning and well-being. The data revealed that assessment methods in the preschool were not systematically planned; rather, issues were discussed in passing and mostly focusing on children's behaviour, including behaviour problems. The participants' ideas developed over the course of the research period. The preschool teachers and assistant teachers created methods to observe children's play, to reflect on and document Learning Stories, originally developed in New Zealand, showing children's abilities and interest in play and other activities. In the middle of the research period, the preschool participants discovered that they had not documented stories about all the children. Some children seemed to be "hidden", they had not caught the staff's attention and thus no Learning Stories had been developed for them. To pay closer attention to these children the preschool teachers and the assistant teachers decided to map the social situation of children in the preschool by focusing on their strengths by documenting their Learning Stories. At the end of the research period they had documented stories about all the children and were able to better understand all the children's welfare and ways of learning and interacting in the preschool. 
During the research period, regular visits were made by the master's student who supported the preschool teachers and the assistant teachers and followed the progress of the research by generating data. In these visits the master's student and the participants in the preschool discussed the process of the children's learning and the challenges they meet with in developing the Learning Stories. Also they reflected on the Learning Stories and the experience became an encouragement to continue documenting children's stories, gaining insight into children's play and learning and being part of the research team.

As the participants in the preschool reflected on the documentation the focus on children's well-being became stronger and at the same time less attention was given to behaviour problems. The preschool teachers were able to use their professional experience and education to make their work with the children more meaningful. The assistant teachers, not having been trained in the field of early education, gained new experience through participating in this research. Their views and methods became closer to the professionals' ideas and seemed to have deepened as had their awareness of the children's views and their well-being. This encouraged change in the preschool practice, as the staff paid more attention to the children who had been "hidden" and were able to support their wellbeing and involvement in the group of children.

Thus, the Learning Story Approach gave the participants in the preschool a new insight into the children's world and they were able to pay closer attention to the learning and well-being of all children.

Key words: Assessment, well-being, collaborative action research, early childhood education and reflective professional development.

\section{Um höfundana}

Daníel Steingrímsson (danieliceland@gmail.com) er deildarstjóri í Leikskóla Seltjarnarness. Hann útskrifaðist með M.Ed.-gráðu í menntunarfræðum leikskóla vorið 2019. Hann er með BA- og MA-gráðu í guðfræði.

Kristín Karlsdóttir (krika@hi.is) er dósent í menntunarfræði ungra barna við Menntavísindasvið Háskóla Íslands. Kennsla hennar og rannsóknir snúa að ígrundun og fagpróun leikskólakennara, pátttöku barna í leik og námi, börnum sem áhrifavöldum í eigin lífi og lýðræðislegu leikskólastarfi. Auk pess hefur hún fjallað um námssöguskráningar og mat í leikskólastarfi. Hún er forstöðukona RannUng og hefur tekið pátt í nokkrum samstarfsrannsóknaverkefnum.

\section{About the authors}

Daníel Steingrímsson (danieliceland@gmail.com) is a department head in Seltjarnarnes preschool. He received his M.Ed. in early childhood studies in spring 2019. He has a $\mathrm{BA}$ and an MA in theology.

Kristín Karlsdóttir (krika@hi.is) is an associate professor in Early Education at the Faculty of Education, University of Iceland. Her teaching and research touches upon preschool teachers' reflections and professional development, children's participation in play and learning, children's agency and democracy in preschools. Furthermore, she works with Learning Stories, documentation and assessment in preschool education. Currently she is head of the Research Center in early education and has taken part in several collaborative action research projects. 


\section{Heimildir}

Bae, B. (2009). Children's right to participate: Challenges in everyday interactions. European Early Childhood Education Research Journal, 17(3), 391-406. DOI:10.1080/13502930903101594

Blaiklock, K. E. (2008). A critique of the use of learning stories to assess the learning dispositions of young children. New Zealand Research in Early Childhood Education Journal, 11(1), 77-88.

Broström, S., Jóhanna Einarsdóttir og Pramling Samuelsson, I. (2018). The Nordic perspective on early childhood education and care. Í B.V. Oers og M. Fleer (ritstjórar), International handbook of early childhood education (bls. 867-888). New York: Springer.

Carr, M. (2001). Assessment in early childhood education: Learning stories. London: Paul Chapman.

Carr, M. (2011). Young children reflecting on their learning: Teachers' conversation strategies. Early Years, 31(3), 257-270. DOI: 10.1080/09575146.2011.613805

Carr, M. (2014). Play and playfulness: Issues of assessment. Í L. Brooker, M. Blaise og S. Edwards (ritstjórar), The Sage handbook of play and learning in early childhood (bls. 264-276). London: Sage.

Carr, M. og Lee, W. (2012). Learning stories. Constructing learner identities in early education. Los Angeles: Sage.

Carr, M. og Lee, W. (2019). Learning stories in practice. Los Angeles: Sage.

Dahlberg, G., Moss, P. og Pence, A. (2007). Beyond quality in early childhood: Education and care (2. útgáfa). London: Routledge.

Dweck, C. S. (2017). Mindset. Changing the way you think to fulfil your potential. London: Robinson.

Dweck, C. S. og Leggett, E. L. (1988). A social-cognitive approach to motivation and personality. Psychological Review, 95(2), 265-273.

Heiða Mjöll Brynjarsdóttir. (2015). „Við erum alltaf að reyna að fá gullin til að glóa meira “: Gildi námssagna í leikskólastarfi (óutgefin meistararitgerð). Sótt af http://hdl.handle.net/1946/22993

Johansson, E. (2004). Lear ning encounters in preschool: Interaction between atmosphere, view of children and of learning. International Journal of Early Childhood, 36(2), 9-25.

Jóhanna Einarsdóttir. (2008). Pátttaka barna. Í Jóhanna Einarsdóttir og Bryndís Garðarsdóttir (ritstjórar), Sjónarmið barna og lýdraæði i leikskólastarfi (bls. 115-133). Reykjavík: Háskólaútgáfan og RannUng.

Jóhanna Einarsdóttir. (2017). Opportunities and challenges in Icelandic early childhood education. Í C. Ringsmore og G. Kragh-Müller (ritstjórar), Nordic social pedagogical approach to early years (bls. 63-72). New York: Springer.

Knauf, H. (2017). Documentation as a tool for participation in German early childhood education and care. European Early Childhood Education Research Journal, 25(1), 19-35. doi:10.1080/1350293X.2015.1102403

Kristín Karlsdóttir. (2017). Children's learning processes in two preschools. Reykjavík: Háskóli Íslands.

Kristín Karlsdóttir og Anna Magnea Hreinsdóttir. (2015). Námssögur:Tæki til að meta áhuga, virkni og líðan barna í leikskóla. Netla - Veftímarit um uppeldi og menntun. Sótt af http://netla.hi.is/greinar/2015/ryn/008.pdf

Kristín Karlsdóttir og Bryndís Garðarsdóttir. (2008). Námssögur: Styrkleikar og færni leikskólabarna. Í Jóhanna Einarsdóttir og Bryndís Garðarsdóttir (ritstjórar), Sjónarmið barna og lýðraði í leikskólastarfi (bls. 49-71). Reykjavík: Háskólaútgáfan og RannUng.

Kristín Karlsdóttir og Bryndís Garðarsdóttir. (2010). Exploring children's learning stories as an assessment method for research and practice. Early Years, 30(3), 255-266. DOI: 10.1080/09575146.2010.506431

Laevers, F. (1994). The innovative project Experiential Education and the definition of quality in education. Í F. Laevers (ritstjóri), Defining and assessing quality in early childhood education (bls. 159-172). Leuven: Leuven University Press.

Lansdown, G. (2011). Every child's right to be heard: A research guide on the UN Committee on the rights of the child general comment no. 12. London: Save the Children Fund.

Lillemyr, O. F., Sobstad, F., Marder, K. og Flowerday,T. (2011).A multicultural perspective on play and learning in primary school. International Journal of Early Childhood, 43(1), 43-65. doi:10.1007/s13158-010-0021-7

Lög um leikskóla nr. 90/2008. 
Margrét Héðinsdóttir, Fanný Gunnarsdóttir og Erla Kristjánsdóttir. (2013). Heilbrigði og velferð: Grunnpáttur í menntun á öllum skólastigum. Í Aldís Yngvarsdóttir og Silvía Guðmundsdóttir (ritstjórar ritraðar), Ritröð um grunnpatti menntunar. Reykjavík: Mennta- og menningarmálaráðuneytið og Námsgagnastofnun.

Mayall, B. (2003). Sociologies of childhood and educational thinking. London: Institute of Education.

Mennta- og menningarmálaráđuneytið. (2012). Aðalnámskrá leikskóla 2011. Reykjavík: Höfundur.

Mennta- og menningarmálaráðuneytið. (2013). Demahefti um námsmat í leikskólum. Reykjavík: Höfundur.

Miðstöð PMTO-foreldrafærni [Parent Mangement Training - Oregon]. (e.d.). Um SMT-skólafarni. Sótt af http://www.pmto.is/fagfolk-smt-skolafaerni/skolaverkefni/

New Zealand Ministry of Education. (1996). Te Whāriki. He Whāriki mātauranga mō ngā mokopuna o Aotearoa: Early childhood curriculum. Wellington, NZ: Ministry of Education.

Prout, A. og James, A. (2015). A new paradigm for the sociology of childhood? Provenance, promise and problems. Í A. James og A. Prout (ritstjórar), Constructing and reconstructing childhood: Contemporary issues in the sociological study of childhood (bls. 6-18). London: Routledge.

Samningur Sameinuðu pjóðanna um réttindi barnsins. (1989). Sótt af https://www.althingi.is/lagas/149b/1992018.2c5.html

Sara Margrét Ólafsdóttir. (2013). „Dað skapar velliðan að purfa ekki að keppa við tímann“: Áhrif skipulags á velliðan barna í leikskóla (óútgefin meistararitgerð). Sótt af http://hdl.handle.net/1946/16816

Sara Margrét Ólafsdóttir og Bryndís Garðarsdóttir. (2016). Vellíðan barna í leikskóla: Samstarfsrannsókn. Í Kristín Karlsdóttir og Anna Magnea Hreinsdóttir (ritstjórar), Leikum, larum, lifum (bls. 31-54). Reykjavík: RannUng og Háskólaútgáfan.

Smiley, P. A. og Dweck, C. (1994). Individual differences in achievement goals among young children. Child Development, 65, 1723-1743.

Dórdís Dórðardóttir og Steinunn Helga Lárusdóttir (2016). „,The day the gender system collapses will be a good day": Students memories of being girls or boys. Tímarit um Uppeldi og Menntun, 23(1), 129-147.

Daníel Steingrímsson og Kristín Karlsdóttir. (2020).

„Фað var eitthvað meira parna“: Mat á námi og vellíðan barna.

Netla - Veftímarit um uppeldi og menntun. Menntavísindasvið Háskóla Íslands.

Sótt af http://netla.hi.is/serrit/2020/mat_nam_vellidan_barna_leikskoli/02.pdf

DOI: hhttps://doi.org/10.24270/serritnetla.2020.2 